\title{
O ff-road religion? A narrative approach to fundamentalist and occult orientations of adolescents
}

\author{
Henz Streb
}

\begin{abstract}
Results of qualitative biographical research on Christian fundamentalist converts and de-converts, and on occultist adolescents are presented and documented using case studies. Research focused on life themes and on biographical processes and transformations. Contrastive comparison of the cases resulted in typologies of C hristian fundamentalist biographies and of "ways of dis-enchantment". These indicate that obligation to a tradition is no longer the model for religious socialization. I ts competitors are biographical trajectories which can have the following characteristics: heresy is taken for granted, religious search is like an open life-style preference (accumulative heretic); ritual coping with life themes is predominant; and religious search follows the motive of sensation-seeking. A typology of religious styles is applied as an interpretive framework for (a) explaining the formation of fundamentalist orientations and (b) understanding development and transformation in religious biographies.
\end{abstract}

(c) 1999 The A ssociation for Professionals in Services for A dolescents

\section{Introduction}

The religious landscape has changed. This seems to be the case not only for adults, but more so for adolescents. In Germany we observe, despite declining church participation, substantial private religious interest and activity in adolescents. ${ }^{1}$ For at least $5 \%$ of adolescents, religious engagement means fascination with and involvement in fundamentalist religious and quasi-religious thought systems and rituals, such as N ew A ge and occultism which we are not used to regarding as "religion". It is mainly because of such deviation from mainstream religion in churches and traditional religious organizations that the metaphor of "off-road religion" suggests itself.

On so-called youth occultism, there is some theoretical discussion to which I have made a contribution (Streib, 1996), and there are some quantitative surveys, but only little qualitative biographical research. On Christian fundamentalism in Germany, qualitative biographical research is almost absent. O ur empirical research is thus an attempt to portray portions of the changed religious landscape and to provide qualitative insights into the biographical factors, developments and transformations which are involved when people engage in or have been engaged in such off-road orientations. I present the results of two qualitative biographical research projects recently concluded at the U niversity of Bielefeld.

Reprint requests and correspondence should be addressed to $\mathrm{H}$. Streib, U niversitat Bielefeld, Postfach 100131, D-33501 Bielefeld, Germany (E-mail: hstreib@tgkm.uni-bielefeld.de).

${ }^{1}$ The Shell youth survey (Shell, 1992) documents declining church participation and the surprising private prayer practice of $30 \%$ of adolescents who do not go to church. The recent membership survey of Protestants (Engelhardt et al., 1997) documents that about $20 \%$ of the people who terminate membership in the Protestant church deny that their reason for termination of membership is that they do not need religion any more. 
The first research project analysed Christian fundamentalist converts and defectors. ${ }^{2} \mathrm{As}$ it formed part of a larger study proposed to an Enquete Commission of the German Parliament, which was concerned with "so-called sects and psycho-groups", the study was funded by the German Parliament. Out of a total of 22 narrative interviews with "ex-members" and "insiders", 12 were selected for interpretation. The focus of our analytic interest was directed toward the relation of the "religious career" and biography, on the question of change and continuity of the personality, his or her identity and autonomy.

The second research project, "W ays of Dis-Enchantment. C ase Studies of A dolescents Who A re Fascinated W ith the 0 ccult" is aimed at an analysis of biographical relations and developmental careers of adolescents (mainly 13- to 18-years-old) who are fascinated with the occult. The project was funded by the "Institut für $\mathrm{G}$ renzgebiete der Psychologie und Psychohygiene", in Freiburg, G ermany. O ut of a total of 29 narrative interviews, 15 have been analysed. ${ }^{3}$

\section{Method of analysis - narrative approach}

In both projects we used a combination of sequence analysis as suggested by 0 evermann (O evermann et al., 1979; 0 evermann, 1988; cf., G arz and Kraimer, 1994) and a narrative approach of biographical research developed by Schütze (1981, 1983, 1984). In each case, we started with a sequence analysis of the fully transcribed interview text in order to arrive at a preliminary structure hypothesis of the case. Then, testing the hypothesis and further analysing the biographical type, we applied our narrative interview analysis. The narrative analysis deserves recognition as a tool to identify the deep biographical developmental factors in the subject's biographical past and, more importantly, the follow-up processes of transformation and development within and after leaving such milieus, orientations and engagements. Since narrative approaches are relatively young developments of methodological procedure in research on religion, I will give some background here.

Since the key quality standard of empirical research is unrestrained access to human experience and action, it follows from philosophical and psychological perspectives ${ }^{4}$ that we pay due attention to the narrativity of experience and action, and thus to the narrativity of their representations in the interview text, i.e. to the spontaneous autobiographic storytelling. For the special features of the narrative research methodology, I refer to its semantic and syntactic dimensions. Semantically the narrative relates to everyday language and represents the basic layer of psyche and life-world. Syntactically the narrative allows one to reconstruct the plot of life history and its dynamics in the most comprehensive way possible (Schütze, 1983, p. 285). Thereby it draws attention to time, to narrated time, to diachronicity, and therefore to development in its archeological and in its teleological dimensions, the first reaching backwards and identifying life themes or

\footnotetext{
${ }^{2}$ The final Report of the Enquete Commisssion, including a summary of our research, has been published in 1998, edited by $\mathrm{Dr}$ Bundestag, Referat Offentlichkeitsarbeit, and has been posted on the Internet: http://www.geocities.com/A thens/0 racle/4497/

${ }^{3}$ First case studies are al ready published (cf., Streib, 1994 a, b).

${ }^{4}$ The philosophical and theoretical-psychological background of the narrative approach cannot be developed here. I refer to Schapp (1953), Ricoeur (1983, 1984, 1985, 1990), Bruner (1986), C rites (1971, 1986), G ergen and Gergen $(1983,1986,1988)$, Sarbin $(1986,1990)$ and Sarbin and deRivera (1998).
} 
"themata" ${ }^{5}$ in order to follow up their structuring impact in a person's life, the second investigating the biographical consequences. Dimensions can thereby be reconstructed which are suppressed or not fully conscious to the storyteller him- or herself; spontaneous autobiographical storytelling subverts to a large degree the control of reflection. Thus, in our narrative approach we take the narrative passages as windows to the latent psychodynamics and developmental structures of the interviewee.

Research design of narrative analysis has to find a way to attend especially to the small and the medium range narrative segments in the interview. W e assume that there is a difference between the interviewee's own self-theoretical statements and his or her spontaneous stories. Thus, we temporarily ignore the interviewee's self-theoretical statements (which makes the interview look very different!) and focus exclusively on the narrative segments. 0 nly later will the interviewee's self-theoretical construction be taken into account.

The result of narrative analysis is a typology of biographical trajectories which follows from comparative evaluation (maximal contrast) of "process models" of typical life-courses (cf., Schütze, 1983, p. 288). Such a decidedly qualitative biographical method, of course, does not yield quantifiable data. The methodological rationale is different: to engage in an exploration of the field in order to elaborate a typology which hopefully does not miss an occurrence (cf., e.g., Fuchs-H ein ritz 1998). This means openness to surprise, to unexpected cases. A nd this is what we did indeed find. Some examples are given in the following section.

\section{Case studies}

Because of space limitations in an article like this, I present only two case studies, one from the dis-enchantment sample and one from the fundamentalism project. I have selected two cases representing two of the most interesting biographical types with regard to our theme.

\section{Heike}

Heike (22) grew up with father, mother and, for the first 3 years of her life, with a stepbrother. Besides some nice Sunday excursions and holidays, H eike especially remembers quarrels, brawls and shouting between her parents. Her father frequently had outbursts of rage and her mother, whom she portrays as closer to her, often neglected her and beat her for punishment. Though not explicitly stated in the interview text, H eike's mother seems to have been an alcoholic. Heike was frequently left alone with the door locked when her parents went out for the evening.

Though $\mathrm{H}$ eike had been baptized in the M ethodist (minority) church, religion obviously did not play a role in the family. But H eike, like many of her generation, participated in the confirmation class of the Protestant (mainstream) church in her suburb. H owever, she later converted to $\mathrm{C}$ atholicism. Heike's parents divorced only a few years before the time of the interview, and neither with her father, nor with her mother, could Heike share

\footnotetext{
${ }^{5}$ M y concept of "life themes" refers to N oam's (1990) concept of "themata" (cf., also, N oam, 1985, 1988; Noam et al., 1991).
} 
anything about her religion. When $\mathrm{H}$ eike was about 20-years-old, the relationship with her mother broke down. Just a few weeks before the interview H eike made an attempt to meet her mother again.

A lready in early childhood, $\mathrm{H}$ eike remembers, she saw frightening things and beings at night in her room which her mother could not see when she came to find out why Heike was screaming. H eike talks about some sort of ugly creatures, which were standing at the side of her bed.

I was at home, all on my own, my mother was in with the upstairs neighbor, and then they came and I saw a spider in my corner. Not real, not really real, and I climbed onto the cupboard, how a small tot got onto the cupboard ... and I stayed up there and shouted at the top of my lungs: "M ama, they're there again, they're there again". She didn't understand and I said: "Back there, they're back there". I kept on seeing things, my mother thought I was crazy, but the doctor said I was intellectual and completely healthy.

Later in the interview, $\mathrm{H}$ eike speaks about another experience of that sort:

They were horribly ugly, I don't know how to describe them, the color, they were a sort of green, between green and burnt. A nd they had fire, well they were fairly evil. They kept on following me, they wanted to kill me or something. I only know one thing, there I was, there I slept, there I woke up and then I called for my mother, but she didn't hear me, although I shouted. A nd then I was afraid, then I went to the door, and then I was pulled back from the door to my bed. By something or other. But, I didn't see it, what pulled me. Then I shouted and I nearly died. W ell, then there is my mother, then she, she heard the noise and then she came in then she asked what was wrong with me, I was as white as a sheet, was just barely alive, my heart was hardly beating. Then I said: "Mama, I think I'm dying, they've come to get me, they've come to get me!" That may sound a bit fantastic, like in a film or something.

$\mathrm{H}$ eike remembers similar frightening experiences from the evenings and nights when her parents were out, locking up the telephone, locking the door and leaving her alone with only her cats for company. A bout one such night, she tells us that she heard someone knocking at the door and she got very frightened, trembling and hiding. The cats were her only comfort. But what she feared most was that "they", the frightening beings of her bad daydreams, half human, half animal would come.

Later during early adolescence $\mathrm{H}$ eike started drawing her frightening beings and learned to explain from where they were coming, namely from hell. She tells about a classmate with whom she shared her fantasies and to whom she showed her drawings, which also gave him the ability to see beings which other people were not able to see. But it was only when $\mathrm{H}$ eike was about 16-years-old that she began to engage in occult practices. In a small group that included her mother, they called the demons and H eike had the experience of being the medium. The seances, especially the third, increased H eike's anxiety. She called the beings which she had seen coming to her in her bad daydreams. A nd reading books, especially volumes on archeological art from Babylon, H eike could identify the being. $\mathrm{He}$ was the demon with the name Passusu. All this information and all these occult practices resulted in deep depression and H eike tells about three attempted suicides.

During this time of depression $\mathrm{H}$ eike was also seeking help in traditional religion. But in the Protestant church, where she attended confirmation class, she did not find what she was looking for. However she found it in the context of the Catholic church. One time during mass she saw the priest who was to become the most important person for her from then on. H eike was so deeply irritated by his looking at her, that she knew that he would 
be the one to perform an exorcism. This $\mathrm{C}$ atholic priest was a fundamentalist, and this is how Heike found her way into a fundamentalist piety and thought system in which the existence of her demonic world was not questioned. On the contrary, the demons were taken even more seriously, when exorcised during H eike's (re-)baptism. This was the most beautiful day, the most important event in Heike's life and her storytelling can hardly cover what she experienced. She saw the light; she felt really at home for the first time in her life; she could talk to God whose presence she felt overwhelmingly. A bout her experience after the baptism ceremony and the communion, H eike says:

I didn't want to leave. W hen they called me away to celebrate ..., I wanted to stay, I said, give me some more, give me a bit more! W ell, that was a completely new experience, and suddenly the happiness, the warmth and what you suddenly feel within yourself, it was as if someone had put a coat around me for protection and said ... that's what it was like. That God held me in his arms. That's what it was like.

At the time of the interview, Heike was still strongly involved and immersed in this fundamentalist milieu. Her room, where the interview took place, was crammed with statues of the Holy V irgin.

\section{Thomas}

Thomas (48) lived during his childhood and youth in a big city in N orthern Germany. A fter high school he went to university to study biology and become a science teacher. A fter his practical training he did not get full-time employment as a teacher for reasons we do not know, but for the following 20 years he earned his living by doing different jobs here and there. A the time of the interview Thomas lived with a woman, her two little children and an 8-month-old infant who was their child. I will relate some of the stations and turning points in Thomas' religious career.

Concerning the reason for his attraction to sects and fundamentalist groups, Thomas tells the story that, when he was a student at the university, it appeared both strange and attractive when a sign hung on the door of his next door neighbor's flat "don't disturb-meditation". Thomas explains his attraction with his feeling at that time:

... I had the feeling, about myself that this is not all, how I live. W ell, it was the search for more intensity ... for a certain kind of release from burdens which I felt which, which perhaps were not always clear ... what it was. But a little lack of freedom, with guilt, being dependent on ... my family, uh, perhaps also a lack of self-confidence, I would say, was a kind of basic structure...

Years later, when Thomas was approaching his second exams in practical training and felt the stress and pressure of these forthcoming exams, he was introduced by a friend to Bhagwan meditation. A fter a first-time visit there, he talks to himself:

... yes man, you also do it ... you also would like to get rid of something. This was not so ... uh I was not clear on this ... there was naturally also a certain curiosity ... this A sian meditation uh .... and that this so with dynamics and then silence, this somehow appealed to me.

Thomas remained for 3 or 4 years in the Bhagwan movement, living in different communes. A s reasons for leaving, Thomas mentions that the ideology of the movement became too narrow for him and that he felt too oppressed and that he was not satisfied with open sexuality. A fter these years his girlfriend had gone to India and Thomas moved 
back to his home town. There, through an old friend, he found his way into a bio-energetics group which, although going by this name, was actually a hard kind of encounter group. Thomas tells us about a 7-day workshop, being closeted in a hall without eating or sleeping and similar exercises every week. But surprisingly, this negative experience is not all that Thomas found there; he describes the experience:

... standing in a position which after some time hurts so much that one begins to scream and to tremble ... uh and then you feel such basic feelings, there appears to be the screaming of three-year-old ... uh or a rage or this and that, then this system of this person was uh really a therapeutic village uh let's say to always always live in therapy ... uh to liberate oneself ...

Thomas also tells us that he also had positive rewarding experiences with this group:

... one has parties, celebrates $\mathrm{N}$ ew $\mathrm{Y}$ ear's Eve, this is like one big family ... everybody knows everybody else, dance with each other ... has a lot of fun, experiences a lot, there again this group, one massages the other, one ... could also perhaps find a partner ... uh ... yes well, that is what attracts...

A fter the death of the group's leader, Thomas leaves the group, and now lives a relatively quiet life, is part of the church choir of a mainstream Protestant parish, and earns his living driving a taxi and from a weekly market business. He then meets Scientology agents on the street and agrees to take a personality test. And, unlike a friend who left Scientology after a first-time visit, Thomas became involved:

... yet I took these tests and somehow I was caught, though I really did not want to go there (fast) I wouldn't have gone there at all first ... but once I was there I said, well, what of it, then also a certain curiosity caught me and certainly this ... this desire again for that ... uh redemption, liberation from the past, from a very burdensome past ... yes, that was it and they promised me something ... they had also a sort of therapy: ... they certainly now uh they are certainly more hard, let's say more stringent, more sectarian than anything I have even seen before...

Thomas describes his attitude toward this new group as different from his attitude toward the previous groups in terms of cost and profit. A nd though Thomas talks extensively about a positive experience in Scientology therapy, the healing of a falling trauma which had plagued him very often in his dreams, his portrait of Scientology is generally negative and critical. He especially felt very uncomfortable with the lie detector. But Thomas was not able to leave the organization of his own volition. This was possible for him only in the context of a new group, which is the last chapter in Thomas' journey through the world of new religious movements and psycho-groups.

It begins, again, by accident. Thomas reads an advertisement "T onight: G ospel M eeting" and follows this invitation. He went to this meeting in a charismatic church, his strange feelings disappeared fast and he was deeply fascinated. Thomas was especially impressed by the story of a nice young woman who told him about Jesus who is alive and has helped her; and Thomas was not sure whether he was infatuated by this woman or by her faith. In any case, he decided to come back for Sunday service. Thomas tells about this event:

.... then I went there, I had to cry so much, I had to go to the toilet because I ... because I could not ... this tight atmosphere, this was somehow ... this gospel church ... let's say in a certain way there .... well ... people relaxed and dancing, with raised hands or also singing, singing out loud and uh not only as I had joined in the singing before... well, they sang ... there was an atmosphere there, it actually smelled of sweat, I thought ah what's going 
on here, like in the body building studio, why does it smell like this ... uhm, this atmosphere touched me in such a way that I had to go to the toilet because I thought I can't suddenly break out in tears here...

This experience touched Thomas so deeply that he remained and became a member of this fundamentalist charismatic church. A nd here he met a woman who advised him strongly to terminate his relation to Scientology; and Thomas reacted immediately, canceled a check and never went to Scientology again.

It appears surprising that, after his extensive tour through groups which are rather critical of Christianity, Thomas obviously had no problems with fundamentalist thinking in this group. This points to a characteristic attitude which we can observe throughout Thomas' tour. The content or doctrinal truth did not play a decisive role in his joining a group; it appears not to make any difference to Thomas except when he felt submission. Then he had to get away. The motivation and critical point for Thomas rather was the excitement, the sensation, the relief and the therapeutic benefit which the group had to offer.

A the time of the interview, Thomas was living a rather quiet life together with this new woman and their children. Faithfulness to this woman is important to him and he tells us that he reads to the children from the children's Bible. Looking back upon his tour through the various groups and organizations he has attended, Thomas uses Biblical language, a quote from Paul to explain in what sense he regards himself as a Christian and maintains that he does not want to be a prisoner of Christ.

... and I did not want to be a prisoner of Christ so to speak ... that uh, I have decided against that, I have realized... insofar I am ... uh, if this is a Christian and when I understand this now as a C hristian, then I am not a C hristian and more ... I am not a disciple of Jesus ... in that sense ... uh ... but I would not say C hristianity is the worst there is, but I would say that I have said there I have experienced liberation, but I have said also ... uh can say also, in this se- where I really say a sect, Scientology ... there this has helped me and ... at Bhagwan that ... has helped me, because in each ... a good friend she says I have taken a little bit from everywhere, from A nthroposophers this, from Bhagwan that ...

W e have no reason to doubt the self-reflective summarizing statement of Thomas. In each group he has found, at least temporarily, some relief. What was Thomas searching for on his tour? C areful reading of the chapters of his story reveals a persistent internal pressure. $\mathrm{He}$ talks repeatedly of a heavy burden which originated in childhood traumas and experiences in his family of origin. Therefore we understand his desire for liberation and ecstasy and his hunger for unconditional love and acceptance as life themes. H owever, for Thomas, conversion is not a once-in-a-lifetime experience, but a repeated experience of getting deeply involved. He could repeatedly find a temporary solution, and ideological constraints and his internal rebellion against submission (most obviously against Bhagwan and Scientology) repeatedly motivated him to leave the groups. In my interpretation, I come to agree with Thomas' self-reflecting statement and therefore call him, in my terms, an "accumulative heretic".

Is Thomas a compulsory convert and a compulsory heretic without any change? By following his narrative carefully, a transformation process becomes visible which has developed during the long tour through all the different groups and movements, at the end of which a more self-assertive, more individual person emerged. $\mathrm{H}$ is al most restless search has come to an end not only in warmth and embeddedness, but also in the responsibility in a nuclear family situation. 


\section{Results of the research projects}

In both research projects, we document the most comprehensive variety which our data samples allow. In the process of selecting the cases for interpretation, and in contrastive comparison, we place a variety of different cases within typological fields. There, also, $\mathrm{H}$ eike and Thomas have their place and location, but the framework is, of course, more comprehensive. Specific foci of analysis have been the life themes (themata) and the biographical effects and developments; they yield a more detailed perspective.

\section{Results from the fundamentalism project ${ }^{6}$}

\section{Themata}

In our analysis of life themes, we did not find (what some in the Enquete Commission had expected us to find) the typical biographical structure of fundamentalist converts or de-converts. There is neither a typical sect biography, nor a typical package of motivational factors. Certainly, we did search the biographical narratives for motivational factors, for "life themes" or "themata", which our interview partners were dealing with in their fundamentalist milieus; and there we identified childhood traumata, childhood anxiety or an unsatisfied hunger for love and acceptance. But in our interview sample, we only found such motivational factors that could also be found in non-fundamentalist biographies.

\section{Typology}

Despite these negative results, there were also positive results. Contrastive comparison of the cases allows one to locate them in a typology. Three types of fundamentalist biographies or "careers" could be identified: (1) a type governed by tradition; (2) the mono-convert, who converts as it were once in lifetime into a religious orientation which he or she did not have before; and (3) the accumulative heretic ${ }^{7}$ whose biography is a tour through different religious orientations and whom I regard as a new type of religious socialization.

W hen the presented case studies are placed in this typology, Thomas appears to be a typical case of the type we have called "accumulative heretic". A Ithough one assumes that, at the time of interview, Thomas is beyond adolescence, he has been chosen here because he is a characteristic case for a new type of religious socialization. H eike could serve as an example of the mono-convert type, and we place her (she is one of the interviewees of the dis-enchantment sample) within this typology.

\section{Biographical effects and developments}

A special focus in our analysis of the interview material has been the biographical dynamics and developments, or the biographical consequences. W e have analysed indicators of transformation and decompensation. The case material revealed, despite the subjects' struggling with traumatic life themata and despite some signs of decompensation, also problem-reducing effects, or indications of transformation. This result contradicts the public opinion that conversion to new religious movements causes psychic decompensation.

\footnotetext{
${ }_{7}^{6}$ For more details, see the research report (Streib, 1998a).

7 "Heretic" does not imply devaluation of deviating religious orientations, but only means the imperative to choose, as Berger (1979) defined the concept when he talks about the "heretical imperative".
} 
During his journey through a variety of religious milieus, including charismatic fundamentalists and Scientology, Thomas underwent a transformation which finally enabled him to cope with his unrelieved desire for unconditional love.

The explanation of such transformations rests upon a theoretical framework of religious styles (Streib, 1997) applied to fundamentalism (Streib, 1998b,c). Based on the structural developmental perspectives on religion (Fowler, 1981, 1987; O ser and G münder, 1984), especially on Fowler's faith development theory, but with significant modifications, e.g. a more decisive focus on interpersonality for which I refer to N oam (1990), the following styles are distinguished: (1) the subjective religious style; (2) the instrumental-reciprocal or "do-ut-des" religious style; (3) the mutual religious style; (4) the individuative-systemic religious style; and (5) the dialogical religious style.

In this framework of religious styles, fundamentalist orientation can be explained as a dislocation of styles: of prevalence of the instrumental-reciprocal or "do-ut-des" style, despite and within the already achieved mutual or individuative-systemic styles. "Do-utdes" (I do in order that you do) is a theological terminus technicus to delineate the intention of religious activities to appease God or the Gods, or to explain their wrath.

Discerning positive developments and outcomes in biographies, therefore, means discerning that transformation of religious styles has taken place, and that the dislocation of styles has been moderated or healed, whereas the actual style of either mutual or individuative-systemic orientation has increased and has come to cover more ground. This may be due to the fact that the themata which caused the individual to fall back on the "do-ut-des" style have declined or disappeared.

In addition to this third result, we found that transformation and decompensation are not distributed equally among the cases. There are differences between the three types. The tendency could be demonstrated that, at the one end, the types governed by tradition suffer more negative consequences and, in some cases, decompensation, while at the other end, the accumulative heretics more often and more easily develop transformation.

\section{Results from the occultism project}

\section{Themata}

The narrative analysis allowed for insights into the biographically (by biographical themata) conditioned preferences for occult world views and practices. Besides other themata such as mourning, because of the suicide of a family member or neglect in early childhood, we found the life theme of anxiety, or rather trying to cope with childhood anxieties, to be prevalent. Imaginary beings like imaginary companions, but of a rather frightening kind, appear sometimes to have a fairly long life; they grow with the child and often mutate into the ghosts and demons which in adolescent occult rituals are called intentionally. The interview with Heike illustrates this. More explicitly than we have found in other interviews, H eike's story makes clear from where the ghosts and demons in occult seances come: from childhood anxieties.

\section{Typology}

The cases can be placed in a typological framework (cf., Streib, 1996) which suggests differentiation in two dimensions of a typological field. (1) Types of expectation: here we differentiate adolescent fascination with the occult according to the motives of (a) sensation-seeking, (b) ritual coping and (c) search for meaning and "ontological 
embeddedness". (2) Types of occult praxis: with regard to the function of magic ritualization (Streib, 1996), we have distinguished magic as an inclusive ritual, as an exclusive ritual, or as a test ritual. On that basis we now distinguish between a first type of serious praxis of inclusion and exclusion (a), on the one end, and a second type test praxis (b), on the other end. W hereas, in the first type, life themes are playing a dominant role, the second type is rather playful and experimental. Between the first and the second type, there is a third type of ambivalent transition, for whom it is an open question whether life themes are re-activated during the occult en gagement.

\section{Biographical effects and developments}

For an in-depth analysis of the developmental dynamic and the future consequences of occult involvement, we need to investigate the ways in which adolescents deal with their occult inclinations and experiences; we have to analyse their defense mechanisms and coping strategies; and this involves also the relation between fascination with the occult and religion. Here a third typological dimension has proved to be a helpful tool of interpretation: the differentiation of styles of magical thinking and acting (Streib, 1996). These styles of magical thinking and acting vary along a scale which parallels the religious styles: it differentiates between (a) appeasing-defensive/oceanic-participative; (b) instrumental-reciprocal; (c) mutual; (d) systemic-controlling; and (e) complementaryintegrative or symbolic styles of magic.

We have found that the deeper the involvement and the higher the expectation, the more likely is a development of decompensation and the need for transformation. In other words, the more the adolescents - whether consciously or unconsciously, whether with high expectation to find a solution or with fear-are revitalizing or "acting out" life themes, the more intense they encounter the dark side within themselves. Because this sort of ritual engagement, as in Heike's case, frequently employs an appeasing-defensive style of magic, the occult involvement is likely to increase anxiety and, in some cases, to lead to suicidal tendencies.

G enerally, I understand transformation of the fascination with the occult as a process of leaving the earlier styles of magic and a readiness for a developmental movement to another style of magic. A dolescents who are decompensating because they engage in compelling magic of the appeasing-defensive style are in need of relief and transformation. For some, this is possible to develop in the context of religious milieus with fundamentalist-spiritistic world views. Only at first sight it is surprising, therefore, that $\mathrm{H}$ eike and a number of other adolescents of our sample ${ }^{8}$ have converted to one of the fundamentalist milieus. For adolescents like $\mathrm{H}$ eike, conversion to a fundamentalist religious milieu has been a significant progress in terms of psychological stabilization. When the converts enter the new religious milieu, nothing changes, especially no detail in the magic-demonic world view, except for one thing: the powerlessness and the defensive-appeasing behaviour is superseded by the newly acquired power to send the ghosts away.

\footnotetext{
${ }^{8}$ Such has been the case for Holger (cf., Streib, 1994a) and Tabea (cf., Streib, 1994b).
} 


\section{Conclusion: changes in the religious landscape}

I conclude with two theses, one regarding the theory and method of biographical research on religion, the other regarding its result, a new perspective on the religious landscape. First, a significant change appears to have taken place in the religious landscape. Besides religiosity guided by tradition and a search for meaning and ontological embeddedness, we encounter new types of religious orientation. The obligation to a certain tradition no longer seems to be the model for religious socialization. It has, however, strong competition from other models, in which heresy-the necessity and burden to choose-is taken for granted or even imperative (Berger), and religious search has become comparable to life-style preference. M ost sensational and challenging for traditional religion is the type we call accumulative heretic. But on closer inspection, we see that conversion, too-as in the mono-convert - has changed and serves goals such as ritually dealing and coping with persistent life themes or even goals of sensation-seeking. In most of these new types, traditional mainstream religions do not play a significant role. The individualism of heresy, of ritual-strategic processes and of sensation-seeking allows and suggests going off-road. A nd a small but growing portion of adolescents takes self-willed adventurous off-road trips to experience and test the transcendent. The self-willed off-road search for ontological embeddedness and the predominance of pertinent life themes in ritual coping may seem strange enough in the eyes of experts and guardians of traditional religion; it appears even stranger when adolescents drive off-road just for fun and sensation.

The "off-road" metaphor may indicate several things: the deviation from mainstream meaning-making and the freedom to do so; the fun of looking for one's own way of seeking sensation; the sometimes hard, risky and fatiguing conditions of such searches; but also the notion that such biographies run contrary to our developmental expectations. Surely not all adolescents are going off-road, but the contribution of such perspectives from the periphery is that the significantly changing ways or modi of joining or leaving religious orientations are documented, which may be attractive not only for the off-road drivers, but also for those on the main roads.

Second, the narrative approach which, as stated above, is an excellent instrument to account for development and transformation, on the one hand, and the interpretive framework of religious styles, on the other hand, correlate perfectly. The methodological tool for empirical research with narrative interviews fits the interpretive perspective which has its roots in developmental psychology. It is on this road that I envision the advancement and modification of structural-developmental theory and research into qualitative biographical research about religion and its transformations in a rapidly changing multi-religious landscape. ${ }^{9}$

\section{References}

Berger, P. L. (1979). The Heretical Imperative. Contemporary possibilities of religious affirmation. N ew York: D oubleday.

Bruner, J. (1986). A ctual M inds, Possible W ords. C ambridge: H arvard U P.

\footnotetext{
${ }^{9}$ A proposal for modifications of the faith development theory (Fowler, 1981) was put up for discussion in my dissertation (Streib, 1991).
} 
Crites, S. (1971). The N arrative Quality of Experience. J.A.A.R., 39, 291-311.

Crites, S. (1986). Storytime. Recollecting the past and projecting the future. In N arrative Psychology: the storied nature of human conduct, Sarbin, T. (Ed.). N ew York: Praeger, pp. 152-173.

Engelhardt, K., V. Loewenich, H. and Steinacker, P. (Eds) (1997). Fremde H eimat Kirche. Die dritte EKD-Erhebung über Kirchenmitgliedschaft, G ütersl oh: G ütersloher V erlag.

Fowler, J. W . (1981). Stages of F aith. San Francisco: H arper \& Row.

Fowler, J. W . (1987). F aith D evelopment and Pastoral C are. Philadelphia, PA : Fortress Press.

Fuchs-Heinritz, W. (1998). Soziologische biographieforschung: überblick und verhältnis zur allgemeinen soziologie. In Biographische M ethoden in den Humanwissenschaften, Jüttemann, $G$. and Thomae, H. (Eds). W einheim: Psychologie V erlags U nion, pp. 3-23.

Garz, D. and Kraimer, K. (Eds) (1994). Die W elt als Text. Theorie, kritik und praxis der objektiven H ermeneutik. Frankfurt/M .: Suhrkamp.

Gergen, K. J. and G ergen, M. (1983). N arratives of the self. In Studies in Social Identity, Sarbin, T. R. and Scheibe, K. E. (Eds). N ew York: Praeger.

Gergen, K. J. and Gergen, M. (1986). N arrative form and the construction of psychological science. In N arrative Psychology: the storied nature of human conduct, Sarbin, T. (Ed.). N ew York: Praeger, pp. 22-44.

Gergen, K. J. and Gergen, M. (1988). N arrative and the self as relationship. In Refiguring the Self and Psychology, Gergen, J. (Ed.). A Idershot: Dartsmouth 1993, pp. 201-240.

H eimbrock, H.-G. and Streib, H. (Eds) (1994). M agie-K atastrophenreligion und K ritik des G laubens. Eine theologische und religionstheoretische Kontroverse um die K raft des W ortes, Kampen: Kok.

Noam, G. G. (1985). Stage, phase, and style: the developmental dynamics of the self. In M oral Education: theory and application, Berkowitz, W. and Oser, F. (Eds). Hillsdale, NJ: Lawrence Erlbaum A ssociates, pp. 321-346.

Noam, G. G. (1988). The theory of biography and transformation. Foundation for clinicaldevelopmental therapy. In Cognitive Development and Child Psychotherapy, Shirk, S. R. (Ed.). $\mathrm{N}$ ew York, London: Plenum Press, pp. 273-317.

Noam, G. G. (1990). Beyond Freud and Piaget: biographical worlds-interpersonal self. In The M oral D omain, W ren, T. (Ed.). C ambridge, pp. 360-399.

N oam, G. G., Powers, S. I., Kilkenny, R. and Beedy, J. (1991). The interpersonal self in life-span developmental perspective: theory, measurement, and longitudinal analyses. In Life-span Development and Behavior, V ol. 10, Baltes, P. B., Featherman, D. L. and Lerner, R. M. (Eds). Hillsdale: Erlbaum, pp. 59-104.

O evermann, U . (1988). Eine exemplarische Fall rekonstruktion zum T ypus versozial wissen schaftlichter Identitätsformation. In Vom Ende des Individuums zur Individualität ohne Ende, Brose, H.-G. and Hildenbrand, B. (Eds). O pladen: Leske+Budrich, pp. 243-286.

Oevermann, U., Allert, T. and Konau, E. K. (1979). Die Methodologie einer 'objektiven Hermeneutik' und ihre allgemeine forschungslogische Bedeutung in den Sozialwissenschaften. In Interpretative V erfahren in den Sozial- und T extwissenschaften, Soeffner, H.-G. (Ed.). Stuttgart: J.B. M etzlersche V erlagsbuchhandlung, pp. 352-434.

O ser, F. and Gmünder, P. (1984). D er M ensch-Stufen seiner religiösen Entwicklung. Ein strukturgenetischer A nsatz. Zürich/Köln: Benzinger.

Ricoeur, P. (1983). Time and N arrative, Vol. I. Chicago: C hicago U P 1984.

Ricoeur, P. (1984). T ime and N arrative, Vol. II. C hicago: Chicago U P 1985.

Ricoeur, P. (1985). T ime and N arrative, Vol. III. Chicago: Chicago U P 1988.

Ricoeur, P. (1990). O neself as A nother. C hicago: U niversity of Chicago Press 1992.

Ritter, W. H. and Streib, H. (Eds) (1997). O kkulte Faszination-Symbole des Bösen und Perspektiven der Entzauberung. Theologische, religionssoziologische und religionspädagogische Annäherungen. N eukirchen-V luyn: N eukirchener.

Sarbin, T. R. (Ed.) (1986). N arrative Psychology: the storied nature of human conduct. N ew York: Praeger.

Sarbin, T. R. (1990). The narrative quality of action. Theoretical and Philosophical Psychology, 10, $49-65$.

Sarbin, T. R. and deRivera, J. (Eds) (1998). Believed-in Imaginings. The narrative construction of reality. W ashington: A PA. 
Schapp, W. (1953). In Geschichten verstrickt. Zum Sein von M ensch und Ding. W iesbaden: B. Heymann.

Schütze, F. (1981). Prozeßstrukturen des Lebenslaufs. In Biographie in H andlungswissenschaftlicher Perspektive, M atthes, J., Pfeifenberger, A. and Stosberg, M. (Eds). N ürnberg: V erlag der Nürnberger Forschungsvereinijung, pp. 67-156.

Schütze, F. (1983). Biographieforschung und narratives Interview. N eue Praxis, 13, 283-294.

Schütze, F. (1984). Kognitive figuren des autobiographischen stegreiferzählens. In Biographie und Soziale W irklichkeit, Kohli, M. and Robert, G. (Eds). Stuttgart: J. B. M etzlersche Verlagsbuchhandlung, pp. 78-117.

Shell, Jugendwerk der Deutschen (Ed.) (1992). Jugend '92. Lebenslagen, 0 rientierungen und Entwicklungen im vereinigten Deutschland, Bd. 1 bis 4, O pladen: Leske \& Budrich.

Streib, H. (1991). Hermeneutics of M etaphor, Symbol and $\mathrm{N}$ arrative in Faith Development Theory. Frankfurt: Peter Lang.

Streib, H. (1994a). Teufelsbeschwörung und Jesus-Zauberspruch-magische $H$ andlungen mit heilender Kraft. In M agie-Katastrophenreligion und Kritik des $\mathrm{G}$ laubens. E ine theologische und religionstheoretische K ontroverse um die K raft des W ortes, Heimbrock, H.-G. and Streib, H. (Eds). Kampen: Kok 1994, pp. 273-283.

Streib, H. (1994b). O kkultismus, religion und lebensgeschichte in der adoleszenz. A rbeitshilfe für den evangelischen Religionsunterricht an G ymnasien, 53, 246-265.

Streib, H. (1994c). Magical feeling and thinking in childhood and adolescence: a developmental perspective. British Journal for Religious Education, 16, 70-81.

Streib, H. (1996). Entzauberung der $O$ kkultfaszination. M agisches $D$ enken und $H$ andeln in der $A$ doleszenz als $\mathrm{H}$ erausforderung an die Praktische Theologie. Kampen: Kok.

Streib, H. (1997). Religion als Stilfrage. Zur Revision struktureller Differenzierung von Religion im Blick auf die A nalyse der pluralistisch-religiösen Lage der Gegenwart. A rchiv für Religionpsychologie, 22, 48-69.

Streib, H. (1998a). A ussteiger, Konvertierte und Ü berzeugte. Kontrastive A nalysen zu Einmündung, Karriere, Verbleib und A usstieg in bzw. aus neureligiösen und weltanschaulichen M ilieus oder Gruppen sowie radikalen christlichen Gruppen der ersten Generation mit besonderer Berücksichtigung der M ilieus und Organisationen christlich-fundamentalistischer Prägung. In $\mathrm{N}$ eue religiöse und ideologische $\mathrm{G}$ emeinschaften und Psychogruppen. Forschungsprojekte und $\mathrm{G}$ utachten der Enquete-K ommission 'Sogenannte Sekten und Psychogruppen', D eutscher Bundestag, EnqueteKommission 'Sogenannte Sekten und Psychogruppen' (Ed.). Hamm: Hoheneck-Verlag, pp. $108-157$.

Streib, H. (1998b). Transformation of religion in the context of fundamentalist milieus (Paper for the World Congress of Sociology, International Institute of Sociology, July 1997, in Köln, Germany, to be published in A nnals of the International Institute of Sociology, Vol. 7, Scheuch, E. K. and Sciulli, D. (Eds)).

Streib, H. (1998c). Generation X Fundamentalism as Challenge to Religious Education (Paper for the A nnual M eeting of the A ssociation of Professors and Researchers in Religious Education). In Proceedings of the A nnual M eeting of A.P.R.R.E. and REA, O rlondo, FL, pp. 391-402. 